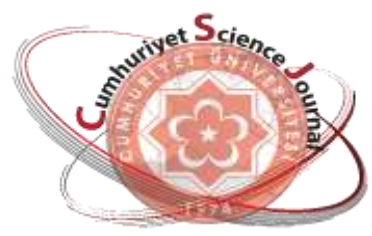

e-ISSN: $2587-246 X$

ISSN: $2587-2680$

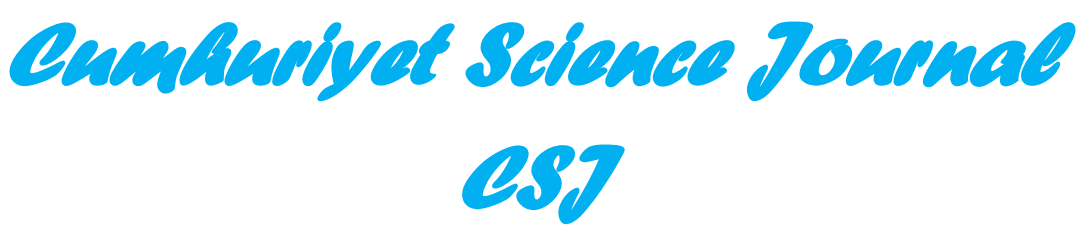

Cumhuriyet Sci. J., Vol.39-1(2018) 181-191

\title{
Removal of Cationic Dye in Aquatic Medium by Using a New Composite Material
}

\author{
Zeynep Mine HASDEMIR ${ }^{1}$, Selcuk SIMSEK ${ }^{2}$

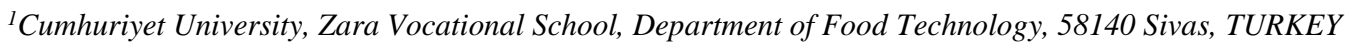 \\ ${ }^{2}$ Cumhuriyet University, Faculty of Science, Department of Chemistry, 58140 Sivas, TURKEY
}

Received: 22.11.2017; Accepted: 15.01.2018

http://dx.doi.org/10.17776/csj.356915

\begin{abstract}
In this study, a new composite material containing polyacrylamide (PAA) and diatomite (D) was developed and characterized for effective removal of Methylene Blue (MB) dye in aquatic medium. The obtained new composite material, polyacrylamide-diatomite (PAA-D) was characterized by point zero charge (PZC), FTIR analysis. The adsorption properties of new composite material were investigated comprehensively and experimental variables were optimized such as concentration, $\mathrm{pH}$, temperature, time and ionic strength. Experimental data were evaluated by using theoretical adsorption models. The maximum adsorption capacity of material was calculated as $0.019 \mathrm{~mol} \mathrm{~kg}^{-1}$ by considering Langmuir equation. The constants calculated from Freundlich and DR model were found as 0.075 and 0.034, respectively. Adsorption kinetic was also explained with pseudo second order and intra particular diffusion models. Experimental studies were showed that adsorption was endothermic and occurred spontaneously. New developed material can be used as potential adsorbent in order to removal of methylene blue from various medium such as wastewater.
\end{abstract}

Keywords: Methylene blue, adsorption, polyacrylamide, diatomite, composite

\section{Yeni Bir Kompozit Malzeme Kullanılarak Sulu Ortamdaki Katyonik Boya Giderimi}

Özet: Bu çalışmada, Poliakrilamid (PAA) ve diatomit (D) içeren yeni bir kompozit materyal sentezlendi ve bir katyonik boya olan metilen mavisinin (MB) sulu ortamdaki gideriminde kullanıldı. Elde edilen yeni kompozit, pliakrilamid-diatomit (PAA-D) sıfir yük noktası (SYN), FTIR analizleriyle karakterize edildi. Yeni kompozit materyalin adsorpsiyon özellikleri kapsamlı olarak ve deneysel değişkenler derişim, pH, sıcaklık, zaman ve iyonik şiddet gibi optimize edilerek araştırılmıştır. Deneysel veriler teorik adsorpsiyon modelleri kullanılarak hesapland. Kompozit materyalin adsorpsiyon kapasitesi Langmiur eşitliğinden $0.019 \mathrm{~mol} \mathrm{~kg}^{-1}$ olarak hesaplandi. Freundlich ve DR modellerinden hesaplanan sabitler 0.075 ve 0.034 olarak bulundu. Adsorpsiyon kinetiği yalanci ikinci derece kinetik ve parçacık içi difüzyon modelleriyle de açıklandı. Deneysel çalışmalar adsorpsiyonun endotermik olduğunu ve kendiliğinden meydana geldiğini gösterdi. Yeni geliştirilen materyal çeşitli ortamlardan atık sular gibi, metilen mavisi katyonik boyasını gidermek için potansiyel bir adsorban olarak kullanılabilir.

Anahtar Kelimeler: Metilen mavisi, adsorpsiyon, poliakrilamid, diatomit, kompozit

\footnotetext{
* Corresponding author. Email address: msenol@cumhuriyet.edu.tr

http://dergipark.gov.tr/csj C2016 Faculty of Science, Cumhuriyet University
} 


\section{INTRODUCTION}

Methylene Blue, is a cationic dye having the $\mathrm{C}_{16} \mathrm{H}_{18} \mathrm{~N}_{3} \mathrm{SCl} \cdot 3 \mathrm{H}_{2} \mathrm{O}$ structure. Methylene blue is an important organic dye widely used in textile, dyeing, printing, pesticide, and coating for paper stock [1]. Due to its aromatic ring, methylene blue is highly toxic and very difficult to degrade [2].

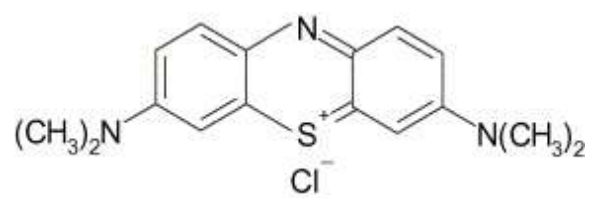

Figure 1. Molecular structure of Methylene Blue.

Various diseases (cancer, mutation, dermatological diseases, etc.) can be seen in case of contact with methylene blue dye. Consequently, the removal of such pollutant matters is exceedingly important for human life and the protection of the environment $[3,4]$.

Several physical, chemical and biological methods are used for the removal of dye [5]. Adsorption is the method of choice and gives the best result as it can be used to remove different types of dye [6,7]. A great deal of low-cost adsorbents, including natural minerals, biosorbents, and waste materials from agriculture and industry, have been used by several researchers. These materials could be used as adsorbents for the removal of dyes from solution [8]. The most used adsorbents are carbon [9], zeolite [10], clay [11], diatomite [12], composites [13] and natural polymers [14] and synthetic polymers [15, 16, 17]. Polymers are mainly preferred due to changeable structural properties according to target species. Selectivity of polymer adsorbents can be increased by using specific molecules having functional groups. Selectivity of polymer adsorbents can be increased by using specific molecules having functional groups [18].
Diatomite $\left(\mathrm{SiO}_{2} \cdot n \mathrm{H}_{2} \mathrm{O}\right)$, a siliceous sedimentary rock available in abundance in various locations around the world, has admitted such as large surface area, porosity, high permeability, high small particle size, low thermal conductivity and chemical inertness. Diatomite can use as low cost mineral for the removal of pollutants from wastewater $[19,20]$.

The aim of the present investigation, a new composite material, PAA-D, was to develop as adsorbent for the removal of methylene blue from an aqueous solution.

\section{EXPERIMENTAL}

\subsection{Reagents}

The raw diatomite used in this study was supplied as a natural mineral from Akmin Mining, Ankara (Turkey). Methylene blue, acrylamide monomer, N,N,N',N'-tetramethylethylenediamine, N,N'methylenebisacrylamide, were purchased from Sigma. $\mathrm{UO}_{2}\left(\mathrm{NO}_{3}\right)_{2} \cdot 6 \mathrm{H}_{2} \mathrm{O}$ and the remaining of the chemicals were obtained from Merck. Ultrapure water was used during all experiments. All chemicals used were of analytical reagent grade.

\subsection{Characterization and instrumentations}

The fourier transform infrared spectroscopy (FTIR) analysis were done to study the functional groups in the range of $400-4000 \mathrm{~cm}^{-1}$ using modified FT-IR spectrophotometer (Bruker, Tensor II) in KBR pellets. The concentration of methylene blue was determined using of a UVvis spectrophotometer (Shimadzu, Japan). A pH meter with a glass-calomel electrode (Selecta, Spain) was used to measure the $\mathrm{pH}$ values. A centrifuge (Hettich Universal) was used to accelerate the phase separation. A thermostated water bath (NuveNT 120, Turkey) was used in order to keep constant the temperature.

\subsection{Preparation of new composite, PAA-D}


For synthesis of PAA-D, a aquatic solution containing $2 \mathrm{~g}$ of $\mathrm{D}$ in $40 \mathrm{~mL}$ was added on to 10 $\mathrm{mL}$ of $10 \mathrm{~g}$ acrylamide monomer solution and 0.2 $\mathrm{g}$ of dissolved crosslinker (N,N'methylenebisacrylamide) in $10 \mathrm{~mL}$ of water and then stirred vigorously for 30 second. Then, 100 $\mathrm{mg}$ of ammonium persulphate was added as starter agent. Polymerization reaction was sustained by adding $200 \mu \mathrm{L}$ of $\mathrm{N}, \mathrm{N}, \mathrm{N}^{\prime}, \mathrm{N}^{\prime}$ tetramethylethylenediamine at room temperature. The obtained new composite was washed with ultra-pure water for several times in order to remove non-grafted reagents. After then, it was dried, ground, and sieved by obtaining a homogeneous material.

\subsection{Determination of methylene blue in the solution and Adsorption studies}

The concentration of methylene blue was determined by absorbance measurement of UVvis spectrophotometer (Shimadzu, Japan) at 665 nm. After a calibration graph was plotted, the concentration of methylene blue was determined in the supernatants.

Adsorptive features of the developed adsorbent were investigated for MB. For this purpose, $0.1 \mathrm{~g}$ of the adsorbent were equilibrated with $10 \mathrm{~mL}$ of $\mathrm{MB}$ in the concentration range of $(0.78-7.8) \times$ $10^{-4} \mathrm{~mol} \mathrm{~L}^{-1}$. The adsorbent-solution systems were equilibrated for $24 \mathrm{~h}$ at $298 \mathrm{~K}$ in a thermostatic water-bath and equilibrium solutions aqueous phase were obtained by centrifuging at
$2.500 \mathrm{rpm}$ for $5 \mathrm{~min}$. The concentration of $\mathrm{MB}$ was determined by absorbance measurement.

\subsection{Point of zero charge and $\mathrm{pH}$ dependence of adsorption}

Points of zero charge (PZC) of new composite material were determined by following the change of $\mathrm{pH}$ at initial and final solutions in presence of $0.1 \mathrm{M} \mathrm{KNO}_{3} .0 .1 \mathrm{~g}$ of adsorbent was interacted with $10 \mathrm{~mL}$ of $0.1 \mathrm{M} \mathrm{KNO}_{3}$ solutions having a $\mathrm{pH}$ in the range of $1-12$ for 24 h. $0.1 \mathrm{M}$ of $\mathrm{HCl}$ or $\mathrm{NaOH}$ were used for $\mathrm{pH}$ adjustments. Final pHs of samples solutions were measured by using a $\mathrm{pH}$ meter. The graph was plotted using initial versus final $\mathrm{pH}_{\mathrm{f}}$ and point of zero charge was determined by the obtained experimental results. For determination of $\mathrm{pH}$ effect on adsorption of $4.7 \times 10^{-4} \mathrm{~mol} \mathrm{~L}^{-1} \mathrm{MB} \mathrm{pH}_{\mathrm{i}}$ of solutions was adjusted in the range of $1-9$. The equilibrium concentrations of the samples were determined by absorbance measurement.

\section{RESULT and DISCUSSION}

\subsection{Characterization of new material}

The characterization of new material was carried out by FTIR technical. The FTIR spectra of PAA, D, PAA-D and PAA-D-MB structures were compared in Fig.2. When it was analyzed the FTIR spectra belong to PAA, D, PAA-D and PAA$\mathrm{D}-\mathrm{MB}$ structures, it can be seen that the desired PAA-D material was obtained successfully. 


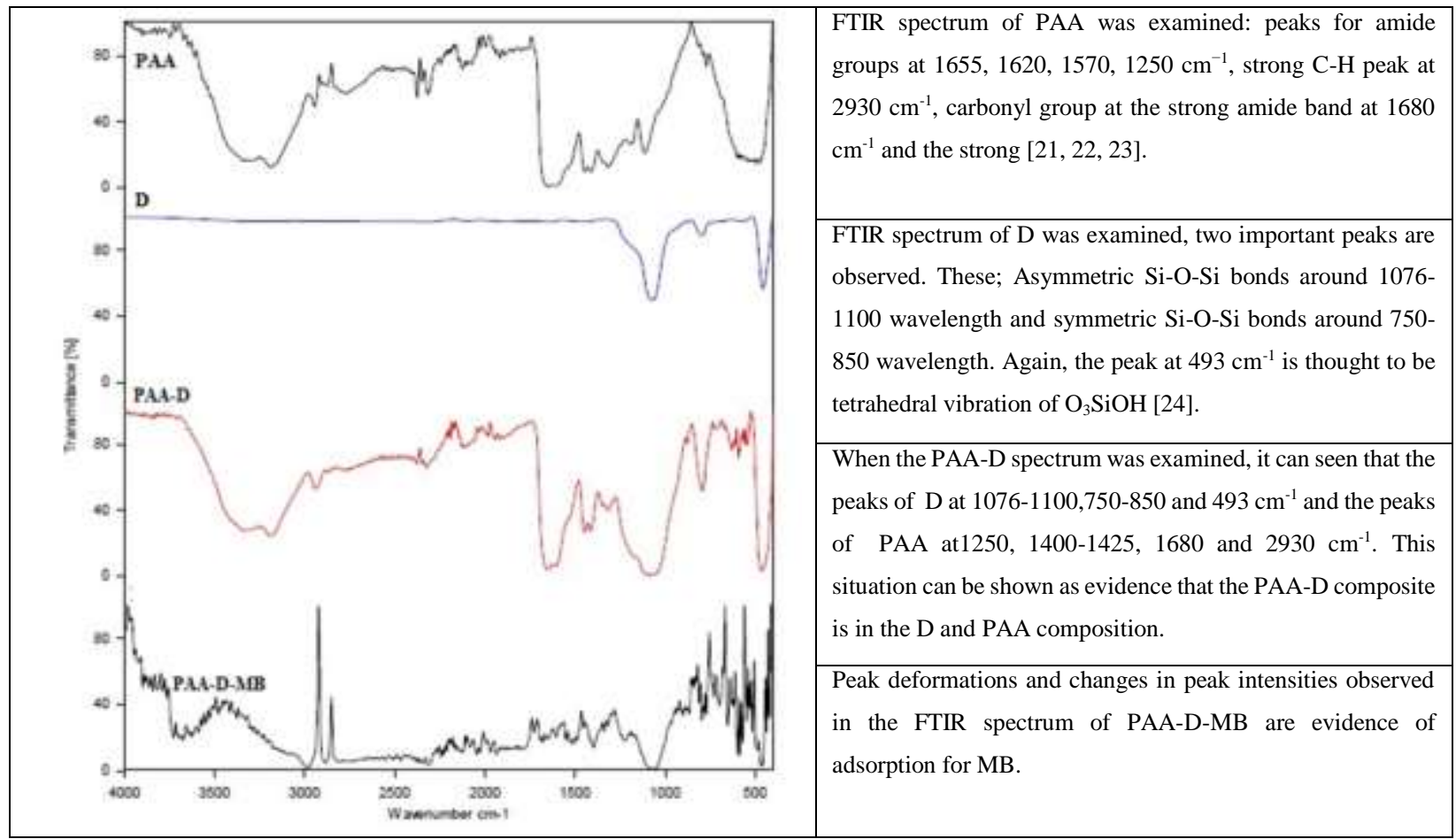

Figure 2. FTIR Spectra of PAA, D, PAA-D and MB adsorbed PAA-D.

\subsection{Influnce of $\mathrm{pH}$ to adsorption}

A series of solutions having different $\mathrm{pH}$ in the range of 1-7 were prepared by using diluted $\mathrm{HCl}$ and $\mathrm{NaOH}$. Test tubes including $100 \mathrm{mg}$ of PAA$\mathrm{D}$ and $150 \mathrm{mg} \mathrm{L}^{-1} \mathrm{MB}$ were treated with these solutions. $\mathrm{pH}$ is one of the main parameters effecting the achievement of adsorption process. Because, both surface charge of adsorbent and ionic charges of species in the medium are depend on $\mathrm{pH}$. The mobility of the other ions in the medium is affected by concentration of $\mathrm{H}_{3} \mathrm{O}^{+}$ ions. Moreover, it also affects interest and capacity of adsorbent for target species. As seen in Fig.3., the MB removal with PAA-D strongly depends on the $\mathrm{pH}$ change of the solution. As can be seen, the most suitable $\mathrm{pH}$ for $\mathrm{MB}$ was $\mathrm{pH}: 7$. At low $\mathrm{pH}, \mathrm{MB}^{+}$and $\mathrm{H}_{3} \mathrm{O}^{+}$ions have a competitive substitution between - $\mathrm{OH}$ and other functional groups on PAA-D, resulting in a decrease in $\mathrm{MB}^{+}$adsorption as $\mathrm{H}_{3} \mathrm{O}^{+}$ions predominate. As a result, there is an interaction between the $\mathrm{OH}^{-}$groups and the negative groups on the adsorbent. Due to the negative charge increases on the adsorbent, there is an electrostatic attraction between $\mathrm{MB}^{+}$and negatively charged groups, as a result of which adsorption is increased. Point of zero electric charge (PZC) experiments also showed that surface charge of adsorbent is negative beyond pH 4.97 and positive the pHs below 4.97 Fig. 4 . So, surface charge is going to negative by increasing $\mathrm{pH}$. Then, as expected adsorption of cationic dye increased in these $\mathrm{pH}$ values. This cationic dye can compete with $\mathrm{H}_{3} \mathrm{O}^{+}$ions and this competition is more at low pHs. This affect decreases with increasing $\mathrm{pH}$. 


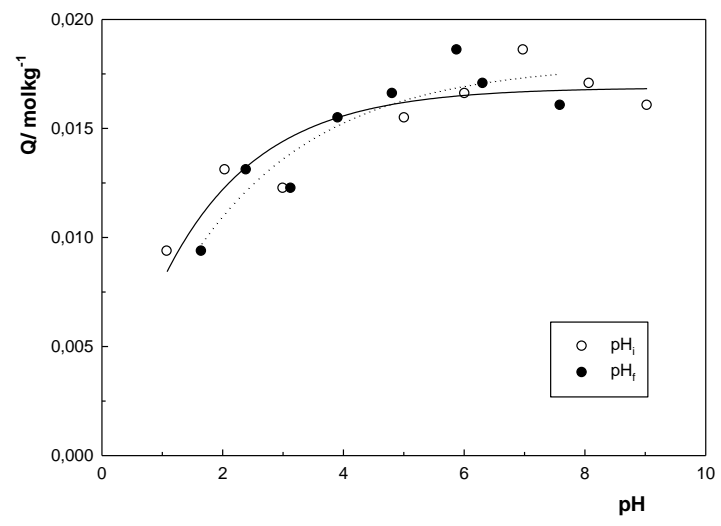

Figure 3. $\mathrm{pH}$ dependence of $\mathrm{MB}$ adsorption.

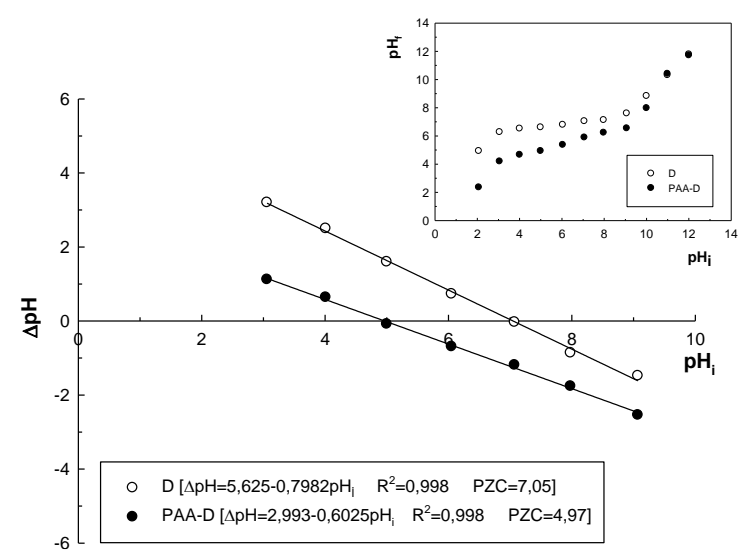

Figure 4. PZC plots of D and PAA-D.

\subsection{Adsorption isotherms}

The adsorption isotherms obtained from experimental results and harmony of this data with theoretical adsorption models (Langmuir, Freundlich, and DR) were illustrated in Fig.5. The required equations and calculated parameters for these models were given in Table 2. Non-linear regression method was applied to results in order to see the harmony between experimental results and theoretical models. From the Langmuir model, the monolayer adsorption capacity was found to be $0.019 \mathrm{~mol} \mathrm{\textrm {kg } ^ { - 1 }}$ and the $\mathrm{K}_{\mathrm{L}}$, which is a measure of adsorption desirability, was found to be $1620 \mathrm{~L} \mathrm{~mol}^{-1}$. As a results of this study, the experimental results are suitable with L-Type adsorption isotherm by considering Giles classification. In view of $\mathrm{R}^{2}$ values which show the harmony of results to adsorption model, the best explanation for adsorption can be given with Freundlich model. Freundlich model explains the tendency of adsorption as hyperbolic plot and submits important information about heterogentyof surface. $n$ value which in the range of 0 and 1 is accepted as a measure of this heterogeneity [25]. From the Freundlich model, $\mathrm{K}_{\mathrm{F}} 0.075$, which is a measure of the adsorption capacity, and $\mathrm{n}$ surface heterogeneity were 0.176 . If $\mathrm{n}$ is less than 1 , surface heterogeneity is increased and the adsorbent is suitable for dye removal.

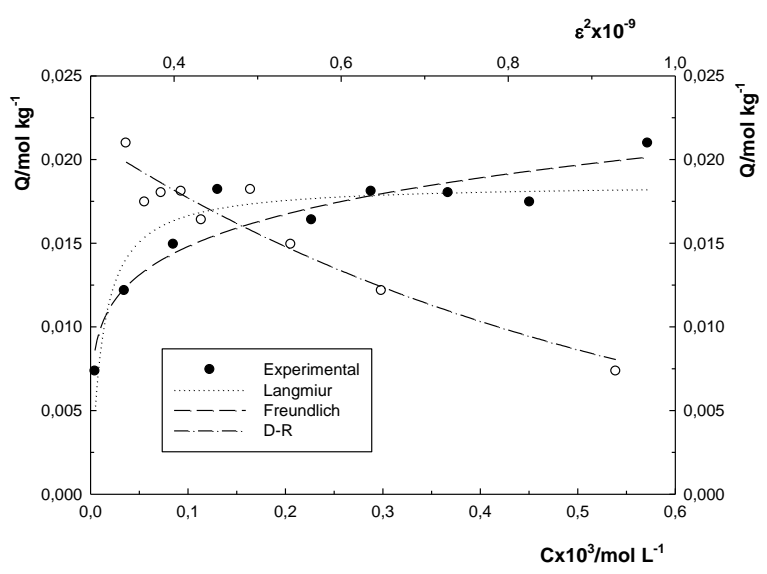

Figure 5. Experimentally obtained adsorption isotherms MB and their compatibility to Lagmiur, Freundlich and D-R models. 
Table 1. Mathematical equation of isotherm models and adsorption parameters.

\begin{tabular}{|c|c|c|c|c|c|}
\hline Model & Equation & Parameters & & & \\
\hline Langmiur & $\mathrm{Q}_{\mathrm{e}}=\mathrm{Q}_{\mathrm{L}} \mathrm{K}_{\mathrm{L}} \mathrm{C}_{\mathrm{e}} / 1+\mathrm{K}_{\mathrm{L}} \mathrm{C}_{\mathrm{e}}$ & $\mathrm{Q}_{\mathrm{L}} / \mathrm{molkg}^{-1}$ & $\mathrm{~K}_{\mathrm{L}} / \mathrm{Lmol}^{-1}$ & & $\mathrm{R}^{2}$ \\
\hline & & 0.019 & 1620 & & 0.843 \\
\hline Freundlich & $\mathrm{Q}_{\mathrm{e}}=\mathrm{KFC_{e } ^ { \mathrm { n } }}$ & $\mathrm{K}_{\mathrm{F}}$ & n & & 0892 \\
\hline D-R & $\mathrm{Q}_{\mathrm{e}}=\mathrm{Q}_{\mathrm{DR}} \mathrm{e}^{-\mathrm{KDR} \varepsilon 2}$ & $\begin{array}{l}Q_{D R} \\
0.0336\end{array}$ & $\begin{array}{l}\mathrm{K}_{\mathrm{DR} \times 10^{9}} \\
18.0\end{array}$ & $\begin{array}{l}\mathrm{E}_{\mathrm{DR}} / \mathrm{kJ} \mathrm{mol}^{-1} \\
18.0\end{array}$ & 0.909 \\
\hline
\end{tabular}

Q: Langmuir monolayer adsorption capacity, $\left(\mathrm{mol} \mathrm{kg}^{-1}\right), \mathrm{K}_{\mathrm{L}}$ :Langmuir adsorption equilibrium constant $\left(\mathrm{L} \mathrm{mol}^{-1}\right), \mathrm{K}_{\mathrm{F}}$ : Freundlich constants, Intensity of adsorption, $\mathrm{n}$ ( $\mathrm{n}$ represents the heterogeneity of the adsorptive surface), $\mathrm{QDR}_{\mathrm{DR}}$ DR adsorption capacity $\left(\mathrm{mol} \mathrm{kg}^{-1}\right), \mathrm{DR}$ constant related to the sorption energy, $\mathrm{K}_{\mathrm{DR}}\left(\mathrm{mol}^{2} \mathrm{~K} \mathrm{~J}^{-2}\right)$, $\varepsilon$ : Polanyi potential given with, $\varepsilon=\mathrm{RT} \ln \left(1+1 / \mathrm{C}_{\mathrm{e}}\right)$, T: absolute temperature, (298 K), R: Ideal gas constant $\left(8.314 \mathrm{~J} \mathrm{~mol}^{-1} \mathrm{~K}^{-1}\right)$, Free energy change $\left(\mathrm{E} ; \mathrm{J} \mathrm{mol}^{-1}\right)$ required to transfer one mole of ion from the infinity in the solution to the solid surface was then derived from $\mathrm{E}=\left(2 \mathrm{~K} \mathrm{~K}^{-1 / 2}\right.$.

\subsection{Adsorption kinetics}

The kinetics results for MB adsorption on PAAD are shown in Fig.6. Adsorption kinetic models were used to analyze the adsorption rate and determine the rate-controlling mechanism of the adsorption process. Kinetic data were analyzed by using pseudo first order (Lagergren Equation), pseudo second order and Weber Morris diffusion models to evaluate the adsorption mechanism and characteristics and the derived parameters are presented in Table 2.
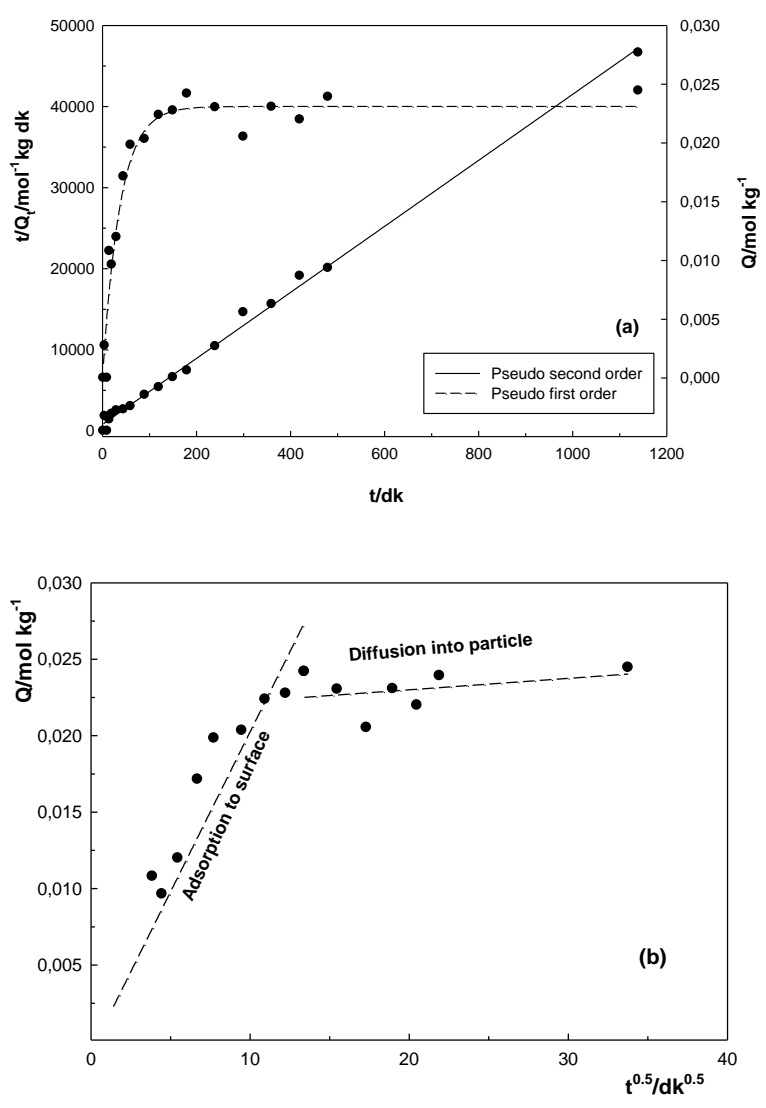

Figure 6. Experimentally obtained adsorption kinetics (a) pseudo first order model and pseudo second order model (b) Weber Morris model. 
Table 2. Mathematical equations of kinetic models and kinetic parameters of adsorption.

\begin{tabular}{lllllll}
\hline Model & Equation & Parameters & & & & \\
\hline Pseudo first order & $\mathrm{q}_{\mathrm{t}}=\mathrm{q}_{\mathrm{e}}\left[1-\mathrm{e}^{-\mathrm{k}_{1} \mathrm{t}}\right]$ & $\mathrm{Q}_{\exp }$ & $\mathrm{Q}_{\mathrm{e}}$ & $\mathrm{k}_{1}$ & $\mathrm{R}^{2}$ & $\mathrm{Hx} 10^{4}$ \\
& & & & & & \\
& & 0.027 & 0.038 & 0.027 & 0.954 & 0.144 \\
Pseudosecond order & $\mathrm{q}_{\mathrm{t}}=\mathrm{t} /\left[\left(1 / \mathrm{k}_{2} \mathrm{q}_{\mathrm{e}}{ }^{2}\right)+\left(\mathrm{t} / \mathrm{q}_{\mathrm{e}}\right)\right]$ & $\mathrm{Q}_{\text {exp }}$ & $\mathrm{Q}_{\mathrm{e}}$ & $\mathrm{k}_{2}$ & $\mathrm{R}^{2}$ & $\mathrm{Hx} 10^{4}$ \\
& & 0.025 & 0.038 & 2.059 & 0.996 & 12.4 \\
Intraparticle & $\mathrm{q}_{\mathrm{t}}=\mathrm{kt}^{1 / 2}$ & - & - & $\mathrm{k}_{\mathrm{i}}$ & $\mathrm{R}^{2}$ & \\
diffusion & & - & - & $2.093 \times 10^{-3}$ & 0.881 & \\
& & - & - & & & \\
\hline
\end{tabular}

$\mathrm{q}_{\mathrm{t}}$ : The adsorbed amounts at time $\mathrm{t},\left(\mathrm{mol} \mathrm{kg}{ }^{-1}\right), \mathrm{q}_{\mathrm{e}}$ : The adsorbed amounts at equilibrium $\left(\mathrm{mol} \mathrm{kg}^{-1}\right), \mathrm{k}_{1}\left(\mathrm{dk}^{-1}\right), \mathrm{k}_{2}\left(\mathrm{~mol}^{-1} \mathrm{~kg} \mathrm{~min}^{-1}\right)$, and $\mathrm{k}_{\mathrm{i}}\left(\mathrm{mol}^{-1}\right.$ $\mathrm{kg}^{-1} \mathrm{~min}^{-1}$ ) are the rate constants, initial adsorption rate, $\mathrm{H}\left(\mathrm{mol} \mathrm{kg}{ }^{-1} \mathrm{~min}\right)$ for pseudo second order is also calculated from $\mathrm{H}=\mathrm{k}_{2} \mathrm{Q}_{\mathrm{e}}{ }^{2}$.

It was observed that $\mathrm{R}^{2}$ values, which show the harmony of experimental data to model, greatly deviated from pseudo second order model. So, it is impossible to explain the adsorption kinetic with this model. The $\mathrm{R}^{2}$ values belong the other model were more suitable to evaluate the kinetic mechanism of adsorption. Kinetic evaluation can also be performed by comparing the ratio of pseudo first and second rate constants $\left(\mathrm{k}_{1} / \mathrm{k}_{2}\right)$ with the fill ratio $\left[\theta_{\mathrm{e}}=\left(\mathrm{K}_{\mathrm{L}} \mathrm{C}_{0}\right) /\left(1+\mathrm{K}_{\mathrm{L}} \mathrm{C}_{0}\right)\right]$, with Langmuir parameter $\left(\mathrm{K}_{\mathrm{L}}\right)$ and initial concentration $\left(\mathrm{C}_{0}\right)$ [26]. The adsorption $\mathrm{k}_{1} / \mathrm{k}_{2} \geq \mathrm{Q}_{\mathrm{e}}$ is defined as the first order, $\mathrm{k}_{1} / \mathrm{k}_{2}<<\mathrm{Q}_{\mathrm{e}}$ and the second order kinetics. According to the results of this research, adsorption kinetics is pseudo second order kinetic for $\mathrm{MB}$; for $\mathrm{MB}, \mathrm{Q}_{\mathrm{e}}=0.432$ and $\mathrm{k}_{1} / \mathrm{k}_{2}=0.013$.

In order to deeply investigate the diffusion of $\mathrm{MB}$ onto the PAA-D composite, the intraparticle diffusion model was used to analyze the diffusion mechanism during the adsorption process. The adsorption of MB into PAA-D can be divided into two consecutive stages. The first stage is the external diffusion stage with interparticle diffusion. The second stage features more gradual adsorption and is controlled by intraparticle diffusion. Results showed that the adsorption of MB on PAA-D structure can be explained with pseudo second order models. The surface of adsorbent is quickly filled at initial by chemical interactions and then intraparticular diffusion process starts slowly.

\subsection{Adsorption thermodynamics}

As shown in Fig.7., the adsorption capacity increased at higher temperature, implying adsorption was an endothermic process. In order to evaluate the effect of temperature on adsorption process, the thermodynamic parameters were calculated by the Van't Hoff equation [27]. The enthalpy change $\left(\Delta \mathrm{H}^{0}\right)$ and entropy change $\left(\Delta \mathrm{S}^{0}\right)$ can be calculated from the equation: The distribution coefficients $\left(\mathrm{K}_{\mathrm{d}}\right)$ were derived from $\mathrm{K}_{\mathrm{d}}=\mathrm{Q} / \mathrm{C}_{\mathrm{e}} \cdot \ln \mathrm{K}_{\mathrm{d}}=-\left(\Delta \mathrm{H}^{0} / \mathrm{RT}\right)+\left(\Delta \mathrm{S}^{0} / \mathrm{R}\right)$. The Gibbs free energy change $\left(\Delta \mathrm{G}^{0}\right)$ can be calculated from the following equation: $\Delta \mathrm{G}^{0}=\Delta \mathrm{H}^{0}-\mathrm{T} \Delta \mathrm{S}^{0}$. 


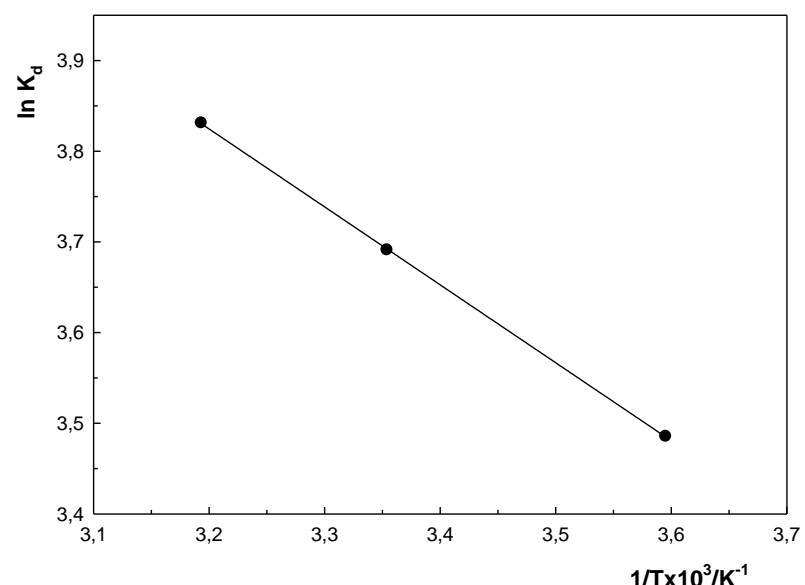

Figure 7. The effect of temperature on MB adsorption.

Table 3. Thermodynamic parameters of adsorption.

\begin{tabular}{llll}
\hline$\Delta \mathrm{H}^{0} / \mathrm{kJmol}^{-}$ & $\Delta \mathrm{S}^{0} / \mathrm{Jmol}^{-1} \mathrm{~K}^{-1}$ & $\Delta \mathrm{G}^{0} / \mathrm{kJmol}^{-1}$ & $\mathrm{R}^{2}$ \\
\hline 7.15 & 54.7 & -9.15 & 0.999 \\
\hline
\end{tabular}

The thermodynamic parameters were calculated and are showed in Table 3 . The positive value of $\Delta \mathrm{H}^{0}\left(7.15 \mathrm{kJmol}^{-1}\right)$ indicates that the adsorption reaction is endothermic. The negative value of $\Delta \mathrm{G}^{0}$ suggests that adsorption is a spontaneous process and at higher temperature adsorption was more favorable. The value of $\Delta \mathrm{S}^{0}$ was 54.7
$\mathrm{J} / \mathrm{molK}^{-1}$, indicating that the adsorption increased randomly at the solid-solute interface.

\subsection{Effect of Ionic strength to adsorption}

The effect of ionic strength on the MB adsorption of PAA-D was investigated for $\mathrm{KNO}_{3}$ inclusions in the range of $0.1-1.0 \mathrm{~mol} \mathrm{~L}^{-1}$ concentration of $150 \mathrm{mg} \mathrm{L}^{-1} \mathrm{MB}$ solution and the results are showed in Fig.8. The increase in ambient ionic strength due to $\mathrm{KNO}_{3}$ concentration shows that MB adsorption does not affect much.

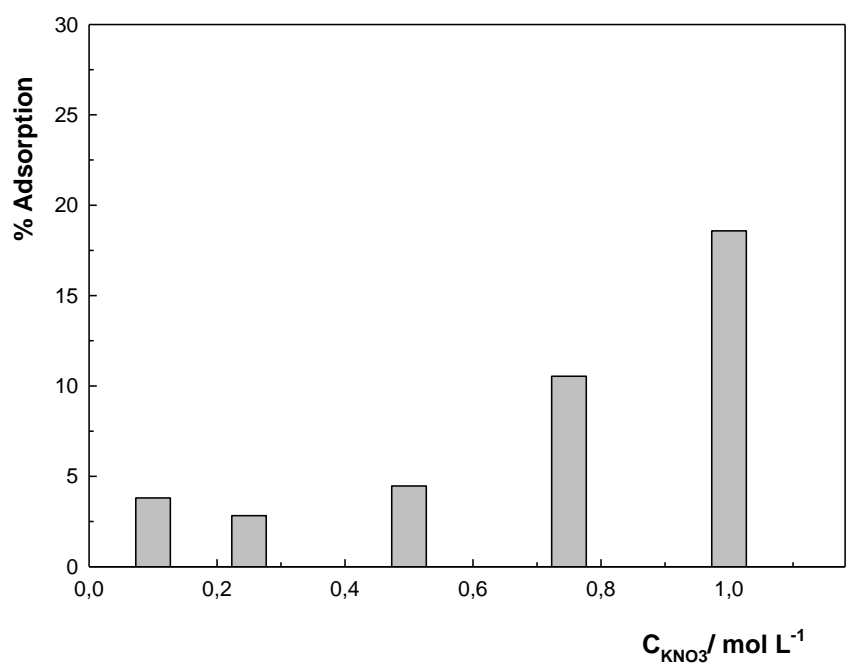

Figure 8. The effect of ionic strenght on MB adsorption.

Table 4. Comparision of various composite adsorbent for removal of MB.

\begin{tabular}{|c|c|c|}
\hline Adsorbent & Capacity $\left(\mathrm{mol} \mathrm{kg}^{-1}\right)$ & References \\
\hline Bentonite/zeolite-NaP composite & 0.113 & [27] \\
\hline Graphene/magnetite composite & 0.137 & [28] \\
\hline Chitosan-clay composite & 0.444 & [29] \\
\hline Attapulgite/bentonite composite & 0.298 & [30] \\
\hline Graphene oxide/calcium alginate composite & 0.568 & [31] \\
\hline Polypyrrole/ $\mathrm{TiO}_{2}$ composite & 0.854 & [32] \\
\hline Crosslinked Chitosan/Bentonite composite & 0.298 & [33] \\
\hline Cross-linked chitosan/sepiolite composite & 0.128 & [34] \\
\hline Polyaniline nanotubes base/silica composite & 0.032 & [35] \\
\hline Polyacrylamide/diatomite composite & 0.019 & This study \\
\hline
\end{tabular}




\section{CONCLUSION}

In this study, polyacrylamide diatomite composite (PAA-D) were synthesized by crosslinking them with N,N'-methylenebisacrylamide and the material was used as a potential adsorbent for removal of $\mathrm{MB}$. Adsorption of $\mathrm{MB}$ from aqueous solution as a function of $\mathrm{MB}$ concentration, $\mathrm{pH}$, time, temperature and ionic strength of adsorbent was investigated. Then, the adsorption data were analyzed and evaluated by conventional model (Langmiur, Freundlich and D-R models). As a result of experimental studies, it was found that adsorption process goes with L-type adsorption model and the maximum adsorption capacity of adsorbent was calculated as $0.019 \mathrm{~mol} \mathrm{~kg}^{-1}$ based on Langmuir model. The constants calculated from Freundlich and DR model were found as 0.0752 and 0.0336 , respectively. The obtained results were explained in the related sections. The kinetic mechanism of adsorption was also studied by using various kinetic model such as pseudo second order, pseudo second order and intraparticle diffusion. Thermodynamic parameters were determined and commented in the related sections. Results showed that adsorption process is endothermic and spontaneously. A table was added in order to compare the proposed method with literature. As can be seen in Table 4, the adsorption capacity of new material is comparable with the other material. New developed material can be used as potential adsorbent to removal of $\mathrm{MB}$ from various medium such as, drinking waters, industrial wastewaters etc.

\section{Acknowledgments}

The present study (Project no: F-540) was partly supported by Cumhuriyet University Scientific Research Projects Commission (CUBAP), Sivas in Turkey.

\section{REFERENCES}

[1]. Wu. Y.J., Zhang L.J., GaoMa C.L., Ma X.H., Han R.P., Adsorption of copper ions and methylene blue in a single and binary system on wheat straw, J. Chem. Eng. Data, 54 (2009) 3229-3234.

[2]. Long C., Yanhui L., Qiuju D., Zonghua W., Yanzhi X., Emily Y., Jun L., Lijie C., High performance agar/graphene oxide composite aerogel for methylene blue removal, Carbohyd. Polym., 155 (2017) 345-353.

[3]. Kumar P.S., Romalingam S., Sathishkumar K., Removal ofmethylene blue dye from aqueous solutions by AC preparedfrom cashew nut shell as a new low-cost adsorbents, Korean J. Chem. Eng., 28 (2011) 149-155.

[4]. Altundag H., Bina E., Altıntıg E., The levels of traceelements in honey and molasses samples that weredetermined by ICP-OES, B1ol. Trace Elem. Res., 170 (2016) 508-514.

[5]. Ghoreishi S.M., Haghighi R., Chemical catalytic reaction and biological oxidation for treatment of nonbiodegradable textile effluent, Chem. Eng. J., 95 (2003) 163-169.

[6]. Jain A.K., Gupta V.K., Bhatnagar A., Utilization of industrial waste products as adsorbents for the removal of dyes, $\mathbf{J}$ Hazard. Mater., 101 (2003) 31-42.

[7]. Derbyshire F., Jagtoyen M., Andrews R., Rao A., Martin-Gullon I., Grulke E., Carbon materials in environmental applications, Chem. Phys. Carbon, 27 (2001) 1-66.

[8]. Mohd R., Othman S., Rokiah H., Anees A., Adsorption of methylene blue on lowcost adsorbents: A review, J. Hazard. Mater., 177 (2010) 70-80. 
[9]. Carboni M., Abney C.W., TaylorPashow K.M.L., Vivero-Escoto J.L., Lin W., Uranium sorption with functionalized mesoporous carbon materials, Am. Ceram. Soc., 52 (2013) 15187-15197.

[10]. Simsek S., Ulusoy U., Uranium and lead adsorption onto bentonite and zeolite modified with polyacrylamidoxime, J. Radioanal Nucl. Ch., 292 (2012) 41-51.

[11]. Campos B., Agular-Carrillo J., Algarra M., Gonc M., Rodriguez-Castellon E., Silva J.C.G.E., Bobos I., Adsorption of uranyl ions on kaolinite, montmorillonite, humic acid and composite clay material, Appl. Clay Sci., 85 (2013) 53-63.

[12]. Caliskan N., Kul A.R., Alkan S., Gokirmak Sogut E., Alacabey İ., Adsorption of Zinc(II) on diatomite and manganese-oxide-modified diatomite: A kinetic and equilibrium study, J.Hazard. Mater., 193 (2011) 27-36.

[13]. Simsek S., Adsorption properties of lignin containingbentonitepolyacrylamide composite for $\mathrm{UO}_{2}^{2+}$ ions, Desalin.Water, 57 (2016) 2379023799.

[14]. Monier M., Abdel-Latif D.A., Synthesis and characterization of ionimprintedresin based on carboxymethyl cellulose for selective removal of $\mathrm{UO}_{2}{ }^{2+}$, Carbohyd. Polym., 97 (2013) 743-752.

[15]. Simsek S., Y1lmaz E., Boztuğ A., Aminemodified maleic anhydride containingterpolymers for the adsorption of uranly ion aqueous solutions, J. Radioanal Nucl. Ch., 298 (2013) 923930.

[16]. Simsek S., Ulusoy H.I., Effective mercury removal using a new developed polymer containing 2-(2 thiazolylazo) $\mathrm{p}$ cresol, Environ. Eng. Manag. J., 15-11 (2016) 2347-2356.
[17]. Simsek S., Senol Z.M., Ulusoy H.I., Synthsis and characterization of a composite polymeric materialincluding chelating agent for adsorption of uranyl ions ions, J.Hazard. Mater., 338 (2017) 437-446.

[18]. Al-Ghouti M.A., Khraisheh M.A.M., Allen S.J., Ahmad M.N., The removal of dyes from textile wastewater: a study of the physical characteristics and adsorption mechanisms of diatomaceous earth, J. Environ. Manag., 69 (2003) 229238.

[19]. Al-Ghouti M.A., Khraisheh M.A.M., Ahmad M.N.M., Allen S., Adsorption behaviour of methylene blue onto Jordanian diatomite: A kinetic study, J. Hazard. Mater., 165 (2009) 589-598.

[20]. Madejova J., Janek M., Komadel P., Herbert J., Moog H.C., FTIR analyses of water in MX-80 bentonite compacted from high salinary salt solution systems, Appl. Clay Sci., 20 (2001) 255-271.

[21]. Chiem L.T., Huynh L., Ralston J., Beattie D.A., An in situ ATR-FTIR study of polyacrylamide adsorptionat the talc surface, J. Colloid Interf. Sci., 297 (2005) 54-61.

[22]. Adhikary P., Tiwari K.N., Singh R.P., Synthesis, Characterization and Flocculation Characteristics of Polyacrylamide-Glycogen, J.Appl. Polymer Sci., 103 (2005) 773-778.

[23]. Yuşan S., U(VI) İyonlarının Ham ve Modifiye Edilmiş Diyatomit Üzerine Adsorpsiyon Özelliklerinin Kinetik ve Termodinamik Olarak İncelenmesi, Celal Bayar Üniversitesi Fen Bilimleri Dergisi, 13 (2016) 761-768.

[24]. Weber W.J., Smith E.H., Simulation and design model for adsorptionprocesses, Environ.Sci. \& Techn., 21 (1987) 10401050. 
[25]. Liu Y., Shen L., A general rate law equation for biosorption, Biochem. Eng. J., 38 (2008) 390-394.

[26]. Neghlani P.K., Rafizadeh M., F.A. Taromi, Preparation of aminatedpolyacrylonitrile nanofiber membranes for the adsorption of metal ions: Comparison with microfibers, J. Hazard.Mater., 186 (2011) 182-189.

[27]. Shaban M., Abukhadra M.R., Shahien M.G., Ibrahim S.S., Novel bentonite/zeolite-NaP composite efficiently removes methylene blue and Congo red dyes, Environ. Chem. Letter, DOI 10.1007/s10311-017-0658-7

[28]. Aia L., Zhangb C., Chena Z., Removal of methylene blue from aqueous solution by a solvothermal-synthesized graphene /magnetite composite, J. Hazard. Mater., 192 (2011) 1515-1524.

[29]. Auta M., Hameed B.H., Chitosan-clay composite as highly effective and lowcost adsorbent for batch and fixed-bed adsorption of methylene blue, Chem.Eng. J., 237 (2014) 352-361.

[30]. Liu Y., Kang Y., Mua B., Wang A., Attapulgite/bentonite interactions for methylene blue adsorption characteristics from aqueous solution, Chem.Eng. J., 237 (2014) 403-410.

[31]. Li Y., Du Q., Liu T., Sun J., Wang Y., Wu S., Wang Z., Xia Y., Xia L., Methylene blue adsorption on graphene oxide/calcium alginate composites, Carbohyd. Polym., 95 (2013) 501-507.

[32]. Li J., Fenga J., Yana W., Excellent adsorption and desorption characteristics of polypyrrole/TiO2 composite for Methylene Blue, Appl.Surf. Sci., 279 (2013) 400-408.

[33]. Bulut Y., Karaer H., Adsorption of Methylene Blue from Aqueous Solution by Crosslinked Chitosan/Bentonite Composite, J.Dispers. Sci. Techn., 36 (2015) 61-67.

[34]. Marrakchia F., Khandaya W.A., Asif M., Hameed B.H., Cross-linked chitosan/sepiolite composite for the adsorption of methylene blue and reactive orange 16, Int. J. Biol. Macromol., 93 (2016) 1231-1239.

[35]. Ayad M. M., El-Nasr A.A., Stejskal J. Kinetics and isotherm studies of methylene blue adsorption onto polyaniline nanotubes base/silica composite, J.. Eng.Chem., 18 (2012) 1964-1969. 